\title{
CLASS MEETS LAND: THE SOCIAL MOBILISATION OF LAND AS CATALYST FOR URBAN CHANGE
}

\begin{tabular}{|r|l|}
\hline Journal: & Antipode \\
\hline Manuscript ID: & ANTI-01-14-P-0020.R2 \\
\hline Manuscript Type: & Paper \\
\hline Keywords: & $\begin{array}{l}\text { social mobilisation of land, class struggle/conflict, urban traditional elites, } \\
\text { creative class, industrial working class, Milan/Bicocca/Pirelli }\end{array}$ \\
\hline
\end{tabular}

\section{SCHOLARONE ${ }^{\text {M }}$ \\ Manuscripts}


Class Meets Land:

\title{
The Social Mobilisation of Land as Catalyst for Urban Change
}

\author{
Maria Kaika \\ Geography \\ University of Manchester \\ Manchester, UK \\ maria.kaika@manchester.ac.uk \\ Luca Ruggiero \\ Dipartimento di Studi Politici \\ Università di Catania \\ Catania, Italia \\ lruggiero@unict.it
}

\begin{abstract}
The paper explores the active yet neglected role that local class struggle over land plays in negotiating new forms of urbanity. Unfashionably shifting research focus from global elites and the "creative class" to local industrial elites and industrial workers, we show that socially embodied local struggles over land are as relevant to globalised urbanisations as they had been to industrial capitalism, and need to be brought back squarely into geographical analysis. We focus empirically on the closely-knitted histories of the Pirelli company, Pirelli's workers, and Pirelli's industrial space at Bicocca (north-east Milan). As we unfold Bicocca's transformation from workers' village $\left(19^{\text {th }}\right.$ century), to radical industrial action hub (1960s-1970s), and finally to trendy mixed-use space (1990s-2000s), we show how, for over a century, social struggles over land remain the terrain on which new forms of urbanity are fought, and highlight two important points. First, class struggle over the economic, social, and symbolic role of industrial land was not the outcome of, but an essential precondition for urban restructuring. Second, the industrial working class and traditional elites were not passive recipients, but active producers of urban change.

L'articolo considera il ruolo fondamentale che il conflitto di classe inscritto nello spazio urbano gioca nella negoziazione di nuove forme di urbanità. L'articolo si discosta dalle analisi in voga sulla classe creativa e sulle élite globali per concentrarsi su élite e lavoratori industriali locali. Il lavoro vuole dimostrare che le lotte tra questi ultimi, per il controllo di determinate porzioni dello spazio
\end{abstract}


urbano, sono rilevanti per l'urbanizzazione globalizzata tanto quanto lo sono state nelle dinamiche del capitalismo industriale, e meritano di essere inserite a pieno titolo nell'analisi geografica. La ricerca empirica si concentra sulla fitta trama di vicende che vedono protagonisti il gruppo Pirelli, i suoi lavoratori e l'area su cui era insediato uno dei suoi principali stabilimenti industriali (Bicocca, nell'area nord-est di Milano). Percorrendo le tappe della trasformazione di Bicocca da 'villaggio dei lavoratori' (XIX secolo) a centro dove si sperimentano nuove forme di lotta operaia (anni '60-'70) e, infine, a nuovo distretto culturale, residenziale e di servizi (anni ‘90-`00), si vuole evidenziare come, per oltre un secolo, il conflitto sociale relativo allo spazio rappresenti il terreno su cui si gioca la costruzione di nuove urbanità. In particolare il lavoro vuole mettere in risalto due punti fondamentali. In primo luogo che la lotta di classe che ruota intorno al ruolo economico, sociale e simbolico dello spazio industriale non è il risultato, ma una precondizione essenziale della ristrutturazione dello spazio urbano. In secondo luogo che la classe operaia e le tradizionali élite industriali non sono destinatari passivi bensì protagonisti attivi della trasformazione urbana.

\section{Keywords}

land, class struggle/conflict, urban traditional elites, creative class, industrial working class, Milan/Bicoccca/Pirelli

\section{Introduction}

By unfashionably shifting attention from global urban elites and the creative class to local traditional urban elites and industrial working class populations, the paper foregrounds the active, yet neglected, role that local class struggle over land played and still plays in enacting urban change. Despite the intense debate and theorizations of the role of land in urban change during the 1970s and 1980s (Castells 1984; Cox 1997; Harvey 1982a; King 1989; Smith 1987; Tribe 1977; Walker 1974, 1975) the debate around land in geographical literature still remains largely theoretical in scope and strangely socially disembodied, with few notable exceptions (Gaffney 2001; Gindin 2003; Haila 2008; Lopez-Morales 2011; Rousseau 2012; Schipper 2013). This paper attempts to rekindle this debate, and bring theory home by foregrounding the century long history of a socially embodied and geographically specific case of class struggle over land at Bicocca (NE of Milan) between Pirelli (one of Italy's most successful companies) and Pirelli's workers.

Instead of favouring one particular conceptual/theoretical perspective on land as a vantage point, our historical geographical excavation aims to foreground how important changes in the social, economic, and symbolic role of land are dialectically related to important shifts in power 
relations and in the terms of engagement in class conflict between capital and labour (Plotkin 1987). Following the century long class struggle between the Pirelli family and Pirelli's workers over the emblematic industrial land at Bicocca, the paper shows how changes in the social, economic and symbolic role of Bicocca's land were dialectically related to important shifts in power relations between capital and labour and changes in the terms of engagement in class struggle. Bicocca was originally construed as a means of production in the accumulation process (1910s) and a way to pacify class conflict within a spirit of industrial paternalism (1920-1940s). But during WWII it became a hub for the Italian anti-fascist workers' movement, and was subsequently (1950s-1970s) claimed by Pirelli's workers as an emblematic social/insurgent space. During the 1980s it was claimed back by industrialists through a process of socio-technological restructuring, in order to be mobilized finally as "pure financial asset" (Harvey 1982a: 347; Haila 1988) during the 1990s and 2000s.

By foregrounding previously neglected actors, and putting 'flesh and bone' into an otherwise largely disembodied debate, we show that renegotiating historical alliances over the use of industrial land was not the outcome, but the necessary means, through which recent urban changes were enacted. We aim to offer three significant insights. First, to establish that local, socially embodied struggles over land are not a defunct aspect of industrial history; they are as relevant to post-industrial capitalism and contemporary urban change, as they had been to industrial capitalism and need to be brought back to the core of geographical scholarship. Second, to highlight that industrial working class populations and traditional urban elites were not the passive receivers of urban restructuring. Instead, they were the protagonists in intense socially embodied struggles that re-negotiated land use changes that made the transition to post-industrial capitalism possible. Third, to affirm that we cannot fully understand the social exclusion and gentrification practices that accompanied urban restructuring, without historicizing the claims over land as an integral part of class conflict (Katz 1986; Walker 1974).

The research presented in the paper is based on archival analysis and interviews conducted over five field visits between 2007 and 2012. Archives consulted include: Istituto per la Storia dell'Età Contemporanea (ISEC); Archivio Storico Industrie Pirelli in Milan (ASIP); Archivo Civico in Milan (ACM); and the archives of Il Corriere della Sera, La Repubblica, Il sole 24 ore and L'Unità. 70 interviews were conducted, including life story interviews with one of the most important trade union leaders of the 1960s (Massimo - pseudonym), and open ended interviews with: 1980s trade union representatives; veteran Pirelli workers; G Nassi, Vice President of Pirelli Real Estate; V Gregotti, architect of 'new' Bicocca; leading Italian academics; new Bicocca residents; and students at Milan Bicocca University. 


\section{Shifting Focus: Industrial Workers and Local Industrial Elites as Active Producers of Urban}

\section{Change}

Over the past 15 years, the main focus of critical urban geography has shifted away from documenting 'traditional' forms of conflict and class struggle over the production of urban space, in favour of developing a systematic inquiry into the role that new urban elites and inter-class alliances, as well as new strategies and forms of urban governance play as active producers of change within a process of urban restructuring (Badcock 1997; Balibrea 2001; Moulaert et al. 2003; Savage et al. 1993; Swyngedouw 2005; Vicari Haddock 2005; Zukin 1995). This body of research generated significant insight by documenting how, on either side of the Atlantic (from Glasgow, Manchester, London, Roubaix and Bilbao1, to Milwaukee, Pittsburgh, New York and Syracuse2), the 'urban regeneration offensive' (Zimmerman 2008), that was supposed to attract new waves of investment and turn declining industrial sites into trendy business, residential, or cultural hubs, led to intensification of social exclusion and the marginalisation of industrial working class populations (Moulaert et al. 2003; Salvini 2014).

However, this body of critical scholarship often analyses land restructuring and the marginalisation or displacement of industrial working class populations as the inevitable, or necessary, outcome of the demand to create post-industrial urban profiles. Hamnett and Whitelegg (2007: 108), for example, argue that "[i]f these changes had not occurred, land-use transformation would not have happened" (see also Ley 1996). Within this framework, industrial working class populations alongside traditional local elites are often depicted as groups that have lost their agency alongside their traditional central role in the production of urban economies, and found themselves at the receiving end of the land and occupational restructuring that followed new governance strategies (Haila 1988).

However, we argue, the shift of emphasis on new protagonists of urban change and the depiction of the industrial working class and traditional local elites as passive recipients or victims of this change, has left a gap in our understanding of a significant process upon which land restructuring is predicated: namely, the transformation of the social and symbolic role of industrial land. This transformation, we contend, was enacted through the historically and geographically specific and deeply socially embodied struggle between industrial local elites and industrial workers. We argue that stripping industrial land off its social and symbolic role as a space over which workers held equal degree of social investment and symbolic jurisdiction as industrialists

1 2012).

See Coq-Huelva (2013); Gómez (1998); MacLeod (2002); Quilley (2000); Rousseau (2009, $2 \quad$ See Brenner and Theodore (2002); Deitrick and Ellis (2004); Hall and Hubbard (1996); Roberts and Schein (1993); Ward (2002); Zimmerman (2002, 2008); Zukin (2004). 
was as important as stripping industrial land off its economic role as condition of production, before any process of urban restructuring could be mobilised. 'Freeing' land from its symbolic and social role as an arena for class struggle became the precondition that subsequently allowed land ownership to perform what, according to Harvey (1982a: 361), is ultimately the only thing pertinent to capitalism, i.e. to "treat land as pure financial asset".

In this article we use the Bicocca case study as a heuristic device to highlight two important points. First, that class struggle over the economic social and symbolic role of industrial land was not the outcome of, but an essential precondition for urban restructuring, and was fought before any practice of urban change or gentrification could be enacted. Second, seen within this context, industrial working class populations and traditional industrial elites were not passive recipients, but active producers of urban change. Unlike the elusive 'creative' classes or footloose global elites who are conspicuously absent from the places where new urban policies are implemented (Rousseau 2009), working class populations and traditional urban elites are physically present and politically and socially active during the very moment of change.

Bringing to the limelight these neglected protagonists of urban change has important epistemological and political implications. First, it highlights the renegotiation of historical alliances over industrial land between workers and industrial elites (with the mediation of urban governance and financial institutions) as a key component of the process that enabled industrial land to be mobilised as a financial asset (Beauregard 1994; Gotham 2009; Haila 1988; Harvey 1982a; Krippner 2005; Walker 1974, 1975). Second, it brings class struggle squarely back into the analysis of recent urban change and foregrounds it as a component that performed not just a coordinating but a transformative role in the transition from industrial to post-industrial urban economies (Clark 1984; Fainstein 1983; Lever 1991; Mollenkopf and Castells 1991; Pollard and Storper 1996; Savitch 1987; Scott 1988). Third, it highlights the efforts of declining industrial capital to mobilize industrial land locally as a financial asset as a drive behind land use change that is arguably more important than speculative moves from global real estate markets, or the agency of the 'usual suspects' of urban change, (governance arrangements, developers, the creative class, etc. - see earlier debates by Brenner 1976, 2006; Cox 1997; Swyngedouw 1992; Walker 1978; Wallerstein 1979).

\section{Bicocca: The Birth of a Space for Industrial Production and Social Reproduction}

Articulating Industrial Paternalism with Taylorism: Land as a Means of Mitigating Capital/Labour Conflict

Pirelli is today one of the most celebrated Italian companies, a multinational conglomerate with net sales of over 4 billion Euros in 2010 (Pirelli \& C SpA 2010). But Pirelli’s story goes back to 1872, 
when Giovanni Battista Pirelli, an entrepreneurial engineer, built a small rubber products factory, which employed forty blue-collar workers and five managers, in a building adjacent to his family home in Milan (Colli 2001; Pirelli 1946). The company grew steadily and diversified production to telephone cables, bicycle tyres and automobile tyres. G.B. Pirelli was amongst the first European industrialists to launch an international advertising campaign which was so successful that by 1913 , Pirelli's exports accounted for 40\% of the company's income (Bolocan Goldstein 2003; Colli 2001; Dalmasso 1970). Production soon outgrew the original factory site. But given the structural barriers, planning restrictions, and high cost of land in Milan's city center, GB Pirelli decided to expand production at the city's outskirts, and to this end bought Bicocca, an agricultural area northeast of Milan, named after the manor house (Bicocca) built there in the 15 th century (Pirelli 1984). In 1917, Pirelli completed the construction of his new production plants on $220,000 \mathrm{~m}^{2}$ of land, and transferred ownership of the remaining 1,152,000 $\mathrm{m}^{2}$ of Bicocca to the Società Quartiere Industriale Nord Milano, a group of banks and industrialists who were developing new industrial districts (Pavese 1997: 134). As more factories located nearby, Bicocca soon morphed into an industrial district and was nicknamed 'The City of Factories' (Irace 1997: 139).

The new Pirelli plant at Bicocca provided state-of-the-art infrastructure. Unlike the old Pirelli factory that had become known as La Brusada (the burnt house), a nickname invoking the insalubrious atmosphere accompanying rubber production, Pirelli's new Bicocca plant featured distinguished brick and glass design and workers who were requested to wear clean uniforms at all times (those assigned to the dirtiest jobs had to wear white uniforms). In building Bicocca, Pirelli made a statement both about production efficiency and factory aesthetics (Irace 1997). The company's steady growth (Colli 2001; Montenegro 1985) was accompanied by GB Pirelli's steady rise in Milan's economic, social and political circles. He became councillor at Milan's City Council (1877-1889), member of the board of directors of Il Corriere della Sera, Italy's oldest newspaper (1895), and finally (1909) Senator (Ciuffetti, 2004; Scotto di Luzio 2001: 358).

However, like in the rest of the industrializing world, the economic and social success of Italian family owned capitalism was soon overshadowed by the proliferation of strikes and industrial upheaval (Benenati 1999: 52). Joining ranks with Italy's political and entrepreneurial elites, G.B. Pirelli expressed publicly his "disquiet about the degenerative effects of larger factories on Italian family values" and defended "small-size enterprises as the way forward for the country's modernization" (Bigazzi 1996: 41). However, GB Pirelli’s own company expanded rapidly and by 1913 employed 3,725 workers at Bicocca, making Giovanni Battista anxious to control this "chaotic crowd ... whose 'deviant' behaviour could become a risk for the production process"(quoted in Galdo 2007: 10).

As strict personnel management and sanctions proved inefficient to control burgeoning trade 
unionism and strikes, Italian entrepreneurs turned to foreign experiments in industrial paternalism in search for an alternative model to manage class conflict (Bigazzi 1996: 38). Creating "a corporate solidarity network [as an] alternative to solidarity based on ethnicity and class" (Benenati 1999: 48) became widely accepted in early twentieth century Italy as an alternative to sanctions, and was supported both by the Catholic Church (De Rerum Novarum), and by the Italian state who saw it as a convenient solution to the increasing demands in welfare provision (Bolchini 1967), and encouraged Italy's enterprises to invest significant resources in social programmes and services for workers (De Grazia 1981). The experimentation with practices of industrial paternalism soon transformed the land NE of Milan into more than just a condition for production. Like in the rest of the industrialised world-from Manchester and London (Cherry 1996; Dewhirst 1960) Paris (Stovall 1990), Montreal (Lewis 2000, 2004), San Francisco (Walker 2001), Pittsburgh (Muller 2001) and Los Angeles (Hise 2001)-the new 'manufacturing suburbs' (Lewis 2004) became not only an inexpensive means of expanding industrial activity, but also an important means to mitigate labour/capital conflict.

It was within this context that Pirelli, in collaboration with the Istituto Autonomo per le Case Popolari (Institute for social housing) embarked upon the construction of a workers' village at Bicocca, the Borgo Pirelli, in the early 1920s (Galdo 2007; Irace 1997; Pirelli 1986). GB Pirelli made a public statement about his commitment to providing social services for his workers, which he saw as a contribution to producing a better capitalism, the "choice of civilisation over socialism, the uncivilized alternative" (quoted in Benenati 1999: 49). Bicocca soon became the showcase for Pirelli's personal version of capitalism; his own signature miniature city (Bigazzi 1996).

While the Borgo Pirelli was still under construction, Mussolini rose to power (October 1922). Fascism proved a great ally to Italian entrepreneurs' efforts to discipline workers. Under Corporativismo, an ideology that disavowed class conflict, the regime abolished both the rights to strike and to hold workers' meetings (Montenegro 1985: 35). Corporativismo, however, was Janusfaced: it also deemed workers' welfare to be the sole responsibility of industrialists, and demanded the provision of social welfare as proof of loyalty to the regime (Agnelli 1930; Benenati 1999; De Grazia 1981). This way, Italy pursued its own particular version of industrial Fordism (Aglietta 1979; Schoenberger 1988) under fascism's close guard (Bigazzi 1996; Bonelli 1978; Cafagna 1990: 396; Hunecke 1978). Between 1929 and 1931 the number of companies that offered leisure and recreational facilities for workers increased from 1,660 to 2,938 (De Grazia 1981: 81). Pirelli also obliged, while Alberto and Piero Pirelli (sons of Giovanni Battista) developed a good rapport with the fascist regime (Anelli et al. 1985: 59).

Whilst the Borgo Pirelli was still in the making, Italian entrepreneurs also started experimenting with 'scientific' personnel management methods (Benenati 1999), and the Borgo 
became an opportunity to embrace both industrial paternalism and Taylorism in one strike. The earlier visit of young Alberto Pirelli to large US tyre production plants (Goodrich, Goodyear, and Firestone) in Akron, Ohio, was instrumental. Alberto Pirelli (1905) wrote to his father: "visiting these factories made me dream ... of building wide halls, [that would help] reach the beautiful production figures they have achieved here. This trip is ... a mind-opener". Inspired by both US scientific management practices, and experiments in industrial paternalism across the western world (Cherry 1996; Dewhirst 1960; Lewis 2000, 2004; Muller 2001; Walker 2001; Walker and Lewis 2001), Pirelli provided Bicocca's workers with tightly managed work places alongside housing, and social services that established the factory as a totalizing dwelling experience. Scientific management expanded from managing workers' bodies on the shop floor, to managing family activities at homes, schools, shops, hospitals, and recreation grounds (Bigazzi 1996; Galdo 2007). Bicocca soon became an emblematic model for technological and social innovation, and granted Pirelli the status of both innovator and benefactor (Bolchini 1967).

But as population density and class homogeneity increased, gradually, Bicocca became to workers not just a place of production and control, but also a basis for communal and political life. Workers started appropriating Bicocca-first symbolically and then materially-as a place for free social and political expression. During the dark years of fascist nationalism, Bicocca became a haven for the circulation of new ideas thanks to the Pirelli family's international outlook and liberal way of running the factories (Bigazzi 1996). Ironically, the same spaces that had been designed to control and anesthetize 'the insubordinate spirit of the workforce' now acted as powerful catalysts for the development of radical ideas and praxis. Bicocca became the stronghold of the anti-fascist National Liberation Committee (Comitato di Liberazione Nazionale - Secchia and Frassati 1965), and Pirelli's middle management turned a blind eye to secret antifascist meetings, whilst the workers' welfare office provided shelter to the politically persecuted (Luciani 1976). In November 1944, 186 Pirelli workers were arrested, of whom 171 were sent to concentration camps at Flossenburg and Mauthausen (Ghianda 1946). L'Unità, the newspaper founded by Antonio Gramsci, described Bicocca as a "citadel of workers' resistance":

"A new fighting spirit based on solidarity and trust [developed there] between people who belonged to different political parties, between workers, technicians, and administrators ... A new life began and [after the end of the war] workers did not want this precious experience to be lost." (Bell 1945)

Despite its workers' militant practices, the Pirelli enterprise thrived during the war years, thanks to contraction of European competition, rise in demand for cables and tyres for military operations, the expansion of telecommunication networks, and the 'social tranquility' promoted by fascist 
authoritarianism (Bolchini 1967).

\section{Italy's Stalingrad: Spaces of Production as Spaces of Resistance}

In the aftermath of WWII, the workers' anti-fascist Comitato di Liberazione Nazionale played an important role in managing Pirelli's factory when Piero and Alberto Pirelli fled to Switzerland after allegations of collaboration with fascism (Anelli et al. 1985). Upon their return (May 1946), the Pirellis assumed full control of the company. But by that time, Pirelli had lost the privileged status it had enjoyed during the fascist years, and was faced with mounting global competition. Finding it increasingly difficult to compete with international giants Pirelli decided to focus their efforts on expanding the national tyre market. This took place within a nexus of Italian corporatist Fordism, where consecutive Christian Democratic governments (1950s-1960s) promoted private car ownership by lowering petrol prices, increasing public transport prices, and expanding the national highway network (Bolchini 1967). Thanks to these indirect subsidies, Pirelli enjoyed a post-war national monopoly status that enabled it to recapture growth.

But Alberto and Piero Pirelli were equally eager to reestablish their kudos and good rapport with workers and the local community. Bicocca became the launching pad for this enterprise. The Pirellis founded the Bicocca Cultural Centre and the magazine Rivista Pirelli as innovative fora for artistic and cultural expression that would "facilitate a dialogue between those who produce and those who buy, which intends ... to go beyond a dialogue around quality and price" (Pirelli 1948). Indeed, both the cultural centre and Rivista Pirelli became important fora for intellectual exchange and progressive political debate. Umberto Eco, Eugenio Montale, and Umberto Saba, amongst others, featured as regular contributors (Bigazzi 1996; Pirelli 1984). The importance that the Cultural Centre and Rivista Pirelli (in print November 1948-January 1972) acquired in political and intellectual life crystallized Bicocca in people's minds as a space of radical political thought and praxis whose scope and reach expanded far beyond the community of Pirelli's workers.

However, Pirelli's good rapport with workers and remarkable recuperation of growth was short-lived (Bertelè 1993). Towards the end of the 1960s, the expansion of national markets became inadequate to offset international competition and the need for technological innovation (Pollard and Storper 1996). The Pirellis reacted to this new crisis with intensification of production and redundancies. This inevitably heightened tension in class relations and ended the short honeymoon period. As economic and working conditions deteriorated, Pirelli's workers (now counting over 12,000) drew upon the considerable experience and solidarity they had amassed during the antifascist resistance and formed two radical workers' groups: the Comitati Unitari di Base (CUB) and the Comitati Unitari di Reparto (CUR) (Bolchini 1967; Dell'Agnese 2005). The CUB and the CUR became famous for mobilizing original forms of industrial action (Bianchi et al. 1971: 11) and for 
being part of the collective that formulated-theoretically and in praxis-what would later become known as 'Operaismo' (D’Agostini 1978; Hayter and Harvey 1993). Italy's more established national left wing workers' organisations were also represented at Bicocca (CGIL, Confederazione Generale Italiana del Lavoro, in particular). However, their proposals were often sidestepped by more radical proposals put forward by the CUB and the CUR (Bolchini 1967). A veteran member recalls the intense militant particularism of the CUB:

"In the first few months of 1968, the CGIL announced strikes but only 10-15\% of Pirelli's workforce took part. Instead, we [the CUB] decided to talk to workers directly at meetings inside the factory and initiate our own strikes by shouting: 'let's forget about trade union membership; let's strike for specific things that matter to $u s$, here, and which affect $u s$, here, in this very factory. Everyone here who is a representative of an official trade union, but not a worker of this factory-get out! Now!'.” (Massimo, Interview, 26 November 2009)

The idea and practice of spontaneous or autonomous industrial action was born at Bicocca:

"We lived like thieves ... under constant fear of being sacked. But we were there everyday at five in the morning distributing leaflets. We gathered everyone together at clocking off, and counted who was in favour of a strike. If we did not achieve a majority of at least $80 \%$ in favour, the strike in that particular department would be called off, and we would go straight back to work. There would be a second attempt in the same department during a different shift, or on a different day. A shift in a department could reach $80 \%$ consensus in favour of industrial action, even if the majority of workers did not belong to the CGIL-CISL-UIL [national trade union organizations ${ }^{3}$ ]." (Massimo, Interview, 26 November 2009)

These fragmented 'autonomous' strikes that 'spontaneously' rotated between different departments and shifts produced chaos and notable damage to the company (see Figure 3). In October 1969, Pirelli's workers paralysed for three consecutive days not only Bicocca, but also Pirelli's headquarters in the centre of Milan. In an iconic moment, Bicocca's workers claimed the expansion of their social and political space into the heart of the city:

"In an affirmationn of class consciousness, workers in white overalls, typical of the dirtiest jobs in

3 The CGIL (Confederazione Generale Italiana del Lavoro) is Italy's historical left-wing trade union with nation-wide membership. CGIL was well represented at Bicocca. The CISL (Confederazione Italiana Sindacati Lavoratori) and UIL (Unione Italiana del Lavoro) are also Italian trade unions with nation-wide memebership. 
Bicocca, linked arms in the open air outside Pirelli's headquarters. There was continuous picketing for 3 days and 3 nights. 24 hours a day. It was as if it were the $25^{\text {th }}$ of April again [the end of the fascist rule]." (Massimo, Interview, 26 November 2009)

Although similar tension and strikes that occurred around the same period at other European plants (notably Renault) “hit workers' wages hard” (Bianchi et al. 1971: 49), industrial action at Pirelli achieved a remarkable increase in salaries (70\% between 1969-1974), the introduction of inflation adjustment, and the reduction of weekly working hours (Bolchini 1985). Pirelli's workers also arbitrated their right to hold meetings in factories before this right was officially sanctioned (Anonymous 1972; Bianchi et al. 1970; Cacciari 1969; Montali 2009; Sclavi 1974). Pirelli’s workers also extended their claims to the symbolic landscapes of Bicocca, by renaming streets after partisan leaders and erecting monuments to resistance workers (Dell'Agnese 2005). The autumn of 1969 became known as the 'Hot Autumn' (Autunno caldo del '69) and the north of Milan acquired the toponym 'Italy's Stalingrad'. It was also during the same period that Bicocca started hosting more violent forms of political action. According to Bolchini (1985: 67):

"some groups started to theorize violence as a form of political expression ... During protests, ... shift managers would often be beaten ... it was at Pirelli where the Red Brigades [notorious 1970s terrorist group] ... and Lotta Continua [radical extra parliamentary group] would meet."

Giovanni Nassi, the son of a Pirelli employee who ascended to vice-president of Pirelli RE, recalls that "the word 'destruction' is no exaggeration. They put bolts into machines, blew up machinery ... three incidents of arson” (Nassi, Interview, 22 February 2007). This period coincided with what later became known as the 'Strategy of Tension', one of the most troubled times in post-war Italian history, during which 140 bomb attacks terrorized the country. No organization claimed responsibility, but conservative media and politicians held the workers' movement responsible. The workers' movement denounced the accusations as conservative conspiracy (Cento Bull 2007). However, despite a series of highly mediatized trials, a culprit party was never established, leaving the workers' movement exposed to allegations of terrorism. This significantly weakened the radical workers' groups, and many workers moved "from participation and heroic action to ... resignation and subordination" (De Luna 2009: 50). In Bicocca, the 'mainstream' national trade union organisations, reformist rather than revolutionary in their demands and action regained strength and greater legitimation amongst Pirelli's workers. The end of the 'Strategy of Tension' signalled the beginning of a new era in class relations, where class conflict would become less overt. Characteristically, the strike hours that had reached 101.7 per Pirelli employee per year in 1969, 
decreased to 46.9 in 1975 and to an average of 25.8 in the following years (1976-1981) (Bolchini 1985: 66, 121; Negrelli 1983). This change was very important when it came to negotiating Bicocca's land as a social space in the decades that followed.

\section{Land Revanchism: Transforming Space and Displacing Class Conflict}

Mobilising Land as an Accumulation Strategy

As Pirelli moved into the 1970s, it faced fierce international competition, significant hikes in the international price of rubber, and an urgent need to invest in new technologies. Between 1971-1975, Pirelli's losses increased from 15 to 27 billion lire (7.7 to 13.9 million Euro) whilst production output declined by 20\% (Bolchini 1985: 71; Pirelli SpA 1976). Although labour militancy was not the main reason behind the company's decline during a period of broader global recession, the legacy of militant industrial action now provided a scapegoat for explaining away Pirelli's bad performance. In the company's 1971 statement, Leopoldo Pirelli (who succeeded his father Alberto and uncle Piero in 1965), insisted that lack of "production recovery" was the direct outcome of "widespread conflict" (Pirelli SpA 1971: 5), and suggested two key strategies to overcome the crisis. The first was outward looking and aimed at improving the company's share in the international market through partnerships and acquisitions (Bolchini 1985). As part of this strategy, Pirelli negotiated a union with the British firm Dunlop, and later launched a hostile takeover against the German firm Continental (Cercola 1984; Colli 2001). Leopoldo Pirelli's second strategy, however, was inward looking and aimed to eliminate the company's two internal 'evils' in one strike-labour militancy and the lacklustre pace of technological innovation. This strategy culminated in Pirelli's proposal to redevelop Bicocca as a 'TechnoCity'.

The land that had originally functioned as a space of production, and a means to mitigate labour/capital conflict but was later socially mobilized by workers as their own political and social space, would now be claimed back by Pirelli in an act of revanchism ${ }^{4}$ that would literally reverse the company's territorial losses. Claiming back this territory previously 'lost' to workers would raise the capital for launching Pirelli into the high-tech tyres sector (Perulli 1986). Giovanni Nassi, who was centrally involved in planning and delivering Bicocca's transformation, recalls vividly the great enthusiasm during the 'Eureka!' moment when Pirelli decided that Bicocca's land could be mobilized as an asset and deliver quick economic returns. Leopoldo Pirelli's TechnoCity was also

$4 \quad$ Whilst acknowledging Smith's (1996) concept of the 'revanchist city', we nevertheless employ the term 'land revanchism' here in a more literal sense, as:"a policy of seeking to retaliate, especially to recover lost territory" (http://www.oxforddictionaries.com/definition/english/revanchism). The word refers to the $19^{\text {th }}$ century French Revanchists, a group of bourgeois nationalists resolved to restore bourgeois order by claiming Paris back from the Communards. We use the word here to denote the process through which capital (Pirelli) literally claimed back territory previously lost to the workers' movement. 
received with great enthusiasm by regional authorities, as it echoed their own vision for reinventing Milan as an international centre for finance, services, and technological innovation (Memo 2007; Nepoti 2003). Unsurprisingly, however, the enthusiasm was not shared by Pirelli's workers. The materialization of the TechnoCity was predicated upon the displacement of a recalcitrant labour force, and the implementation of irreversible changes in the symbolic and material role of the land that had become their own working and living space; a land they had come to perceive as belonging to them as much as it belonged to Pirelli.

In October 1983 Leopoldo Pirelli announced the occupational restructuring at Bicocca (Perulli 1986), and asked workers to enter negotiations. International competition, he explained, demanded investment in the production of high-tech metallic tyres. Bicocca, where $60 \%$ of production was dedicated to 'traditional' textile tyres, had to close down, and production had to be relocated to Pirelli's plants at Settimo Torinese, near Turin, which featured more state-of-the-art infrastructure (Perulli 1986; Nassi, Interview, 27 February 2007). In order to convince trade unions and local authorities that 'freeing' up Bicocca's land for redevelopment would be pursued in both the city's and the workers' best interests, Leopoldo Pirelli mobilized all his clout and powers of persuasion and enrolled his family's track record of commitment to both city and workers: "[the TechnoCity] is a social and cultural contribution that Pirelli will make to the city of Milan. We are convinced, as we always have been, that economic progress cannot ignore [the social and cultural] dimensions of civil life" (Pirelli 1984: 5).

But trade unions remained unconvinced and responded with strikes and a mass demonstration in central Milan (4 November 1983 - Perulli 1986). The CUB and the CUR (grassroots workers' organizations) accused Pirelli openly of using the crisis as a pretext for reestablishing the power relations that prevailed before the 'Hot Autumn' of '69. However this new phase of class struggle was short-lived. Although it was indeed the legacy of the 'Hot Autumn' that had originally compelled Pirelli to invite workers to negotiations over Bicocca's future, the marginalization of the CUB and the CUR after the 'Strategy of Tension' meant that this time his main opponents were the less radical in action and more conservative in scope national trade union organizations. Already in 1976, Sergio Cofferati, executive member of the CGIL (national left-wing trade union) contended that class struggle had to take a more 'pragmatic' turn: "trade unions can no longer contain the effects of the crisis and disavow the need for restructuring by defending every single job and every single plant" (quoted in Bolchini 1985: 119).

The fact was that both sides had a lot to lose if they did not enter negotiations. For Pirelli, forging consensus over plant closures was essential both for facilitating the smoother management of restructuring, and for negotiating more favourable planning terms with local authorities (Perulli 1986). For trade unions, not entering negotiations also incurred risks, as it gave rise to internal 
fragmentation. Already, in September 1984, strong tension was created between the trade unions of Milan and Turin when Pirelli pulled a separate local deal for extending the working week with unions at Settimo Torinese (Perulli 1985). After a long history of emblematic struggles to redefine socially determined work and reclaim places of work as places of freedom and expression, Bicocca's workers now risked losing the very characteristic that had enabled them to enter these struggles in the first place; i.e. their status as Milan's working class par excellence. After having come as close to self-management as any group could get under capitalism, they knew that during a period of rapid economic restructuring, they risked becoming Milan's economic underclass, 5 a class "hopelessly set apart from the nation at large, [not sharing] in its life, ambitions and achievements" (Myrdal 1963: 10 - see also Gans 1993; Mingione 1996). The best they could expect now was to maintain some form of "control of their own economic circumstances" (Walker 1978: 33).

The risks present for both parties brought Pirelli and the unions around the negotiations table during November and December 1984. The City Council, the Provincial Government, and the Regional Authorities played an important role as mediators and guarantors in this new phase of class struggle. On 26 April 1985, trade unions, Pirelli and the local authorities co-signed a Protocol of Intentions (Schema di Protocollo di Intesa), which set the basic rules for restructuring Bicocca (Regione Lombardia 1985). The Protocollo guaranteed employment for "between 1,500 and 1,700 of Bicocca's workers through a combination of early retirement offers, re-deployment at a new plant at Bolatta (that Pirelli undertook to build), and re-employment with the municipality or with companies affiliated with the municipality" (Pirelli 1984: 2-3 - see also Anonymous 1984, 1986; Perulli 1986; Regione Lombardia 1985: 2-3). After the Protocollo was signed, ownership of Bicocca's land was transferred from Pirelli to a new daughter company, Progetto Bicocca, which would oversee land redevelopment (Pirelli 1986 - see Table 1 and Figure 1).

\section{Insert Table 1 around here}

Table 1: Proposed land use for Progetto Bicocca.

Source:Compiled by the authors from Unità Tecnica di Pianificazione Regionale (1988: 42-44); Molinari (1999).

Insert Figure 1 around here

$5 \quad$ Although a full account of the long, heated and important debate over the scope and definition of the underclass lies outside the scope of this article, we should specify that we use the term here in its strictly economic sense, as originally conceptualized by Myrdal (1963) and later developed by Olin Wright (1994); i.e. a class that has become economically 'useless' for capitalism, because their labour has become unworthy of exploitation. 
Figure 1: New Space allocation at Bicocca.

\author{
1. 'Cherry Trees Hill' - Park Area; 2. The Esplanade' Private Residences; 3. Pirelli RE \\ Headquarters; 4. Deutsche Bank offices; 5. Pirelli Cable Research Centre; 6. Pirelli Tyre Research \\ Centre; 7. Office Towers; 8. Siemens Group Offices; 9. University Science Area; 10. University \\ Arts and Humanities Area; 11. La Piazza' Private Residencies; 12. Pirelli -Unbuilt Area; 13. Pirelli - \\ Unbuilt Area; 14. 'Bicocca Village' Commercial and Leisure Centre; 15. 'Hangar Bicocca' \\ Contemporary Art Space and Gallery; 16. 'Teatro degli Arcimboldi' Theatre/Opera; 17. The \\ National Research Council Site; 18. 'Via Emanueli' Private Residencies ; 19. 'Via Sesto San
} Giovanni' Cooperative Residencies.

Source: Courtesy of Gregotti Associati International, modified by authors.

The agreement was a Pyrrhic victory for Pirelli's workers. Although it did protect jobs and prevented relocation, it nevertheless endorsed the disaggregation of the workers' community at Bicocca. Although around 1,000 workers/residents would stay at Bicocca, the heart of what had made this an emblematic space, i.e. the large unified workers' community, would be dispersed. One of the redeployed workers describes the agreement as a "massive defeat":

"They decided it was time to end class struggle ... They decided ... to kill the factories ... Pirelli had been the fulcrum of [class] struggle, of our determination to move from capitalism to socialism; we were close to that change back then ... this foothold consisting of thousands of workers, united and cohesive, and sharing a common vision, had to be dismantled." (Massimo, Interview, 26 November 2009)

The reorganisation of Pirelli's production into smaller, disperse, 'flexible' units meant that the workers' movement, which had drawn significant strength from the dense concentration of production and living spaces on one single site, lost the power to mobilize large masses of workers against centrally made decisions. Indeed, negotiating the TechnoCIty was the last instance when Pirelli involved workers as partners in decision making.

From Tyres to Real Estate: The End of Place-loyal Capitalism and Class Struggle?

Bicocca's redevelopment as a Technocity signaled that land would no longer be an investment bound to depreciate over time, a means to mitigate capital/labour conflict, or a podium for class 
struggle. Land would now be mobilized as pure financial asset that could be brought into the company's balance sheets. The reclamation of Bicocca's land entered its final phase in the 1990s, after Pirelli's failed attempt to launch a hostile takeover of its German competitor, Continental. The failed takeover resulted in a raid against Pirelli itself (Bluestone and Harrison 1982; Dumenil and Levy 2004) and the company came under the guardianship of Mediobanca. The Pirelli family, a paradigmatic example of traditional industrial capitalists, entered (somewhat belatedly) the process of intra-class competition that from the 1970s onwards became dominant in the US (Lever 1991; Pinto 1998; Pollard and Storper 1996; Scott 1988, 1997). Although Leopoldo Pirelli was keen to stay on as CEO, he was 'strongly advised' by Enrico Cuccia, director of Mediobanca, to step down. For the first time in Pirelli's history, the company would not be managed by a Pirelli family member (Il Corriere della Sera, 19 January 1992, 16 February 1992; Nepoti 2003; Pirelli SpA 1992, 1993; Sicca and Izzo 1995; Zanetti 2003).

The new management reduced drastically the workforce (see Table 2), and sold off what was perceived to be 'non-profitable' units (Bertelè 1993: 65; Fumagalli and Mocera 2007; La Rebubblica 24 November 2008; Zanetti 2003). Il sole 24 ore reported in 1994 that "the Tronchetti [new Pirelli CEO] cure produced 55 billion lire [28.4 million Euro] in profit and a marked reduction in debt" (Il sole 24 ore 24 September 1994). Global financial analysts also applauded the 'cure' and encouraged further restructuring (Bertelè 1993: 63). By contrast, Gianmario Mocera, representative of Filcem CIGL (trade union for chemical, rubber and plastics sector) depicts the selling of "perfectly functioning units" as:

“... part of a strategy of dismissals, which did not compensate for the huge debt accrued from the failed acquisition. Approximately 3.7 billion lire in debt [1.9 million Euro] weighed on the company and the sales brought in less than 1 billion lire [0.5 million euro]." (Gianmario Mocera, Interview, 29 September 2009 - see also Fumagalli and Mocera 2007)

\section{Insert Table 2 here}

Table 2: Changes in workforce after Pirelli's restructuring, 1991-1993.

Source: Pirelli SpA, Relazione e Bilancio al 31 Dicembre 1991-1993.

But whilst Pirelli was undergoing major restructuring, its daughter company Progetto Bicocca, was delivering the first redevelopment project of seven new office buildings at Bicocca on a 75,000 square meters site (La Rebubblica 30 May 1989). According to Nassi, who was managing the 
redevelopment, this was an "ugly" project, built with no particular attention to design quality, but with an eye towards quick capital return (Nassi, Interview, 22 February 2007). The impressive economic returns that this "ugly" project yielded prompted Pirelli's new management to turn real estate into core business by instituting a new company, Milano Centrale Immobiliare (MCI) in 1992 (Memo 2007; Nepoti 2003). Soon, any idea for production recovery was shelved (1993), and the TechnoCity project itself was abandoned as “too demanding”. It was replaced by a plan for turning Bicocca into a 'Historical Centre in the Suburbs', a speculative mixed use real estate venture which comprised luxury homes, offices, research centres, and cultural functions (see Figure 4 and Table 1). In 1994, the University of Milan acquired around 40\% of Bicocca's land and buildings (Nepoti, 2003), and offered the new Bicocca its first landmark public project: Università di Milano-Bicocca. The construction of the Arcimboldi theatre (also publicly subsidised), acted equally as an imagemaking tool, showcasing Bicocca's post-industrial urbanity.

During the second half of the 1990s, MCI became one of the most important Italian real estate companies and was renamed Pirelli RE (Pirelli Real Estate). Pirelli RE commissioned its new iconic headquarters at Bicocca to 'starchitect' Vittorio Gregotti; the design comprises a spectacular glass cylinder engulfing the old Pirelli cooling tower (Memo 2007) "symbolic of the shift from industrial production to the service sector. In this building, Pirelli's past and present coexist" (Gregotti, Interview, 14 November 2007). The reinvention of Bicocca as a real estate speculative venture signalled the beginning of Pirelli's "search for enhanced future ground rents" (Harvey 1982a: 368) and marked the final act of reclaiming Bicocca's land from workers not only materially, but also at the symbolic level.

\section{Decaffeinated Urbanity and Bicocca as No Man's Land}

With the majority of workers removed, the social spaces that had emblematized Bicocca as an arena for radical political thought and praxis were lost. As the newly developed sites at Bicocca are physically dislocated both from the old workers' village and from the fabric of Milan's city centre, the new Bicocca presents a case in point of a rupture in urban space (Harvey 1982b; 1989). The much celebrated monumentality and 'neutrality' of Gregotti's architecture is set in stark contrast with the remnants of the more humble but history-rich fabric of the workers' village. Biccoca's remaining original residents do acknowledge the cosmetic improvements that the redevelopment has brought, but cannot come to terms with the erasure of their reference points, their memories and their landmarks. For example, not one amongst 20 of Bicocca's original residents, whom we interviewed, had heard about or could relate to Hangar Bicocca, the contemporary art space that lies at their immediate vicinity. Casa Loca, now a squatted place near Bicocca advertised by real estate agents as a 'colourful and rebellious landing place' for students, residents, and visitors, holds 
a very different significance to Bicocca's original inhabitants as a space "swarming with workers engaged in lively political discussions every moment of the day, every day of the week, including weekends" (Pirelli Village Resident 12, 2 October 2009). The owner of one of Bicocca's few shops that resisted transformation remembers: “ ... an incessant movement of buses that used to stop in front of my shop and take the workers to the factory, every day, even on Sundays" (Old Resident 3, Interview, 2 October 2009). Vicari Haddock et al. (2005) also document that Bicocca's inhabitants old and new lament the lack of food shops, meeting spaces, police stations, schools, churches, and health centres. In an effort to rescue at least at the symbolic level some of Bicocca's rich history, a veteran worker pledged with the City Council to "name new squares or streets after Pirelli's workers who died in concentration camps in 1944" (Letter to Milan City Council, 27 January 2008, Personal Archive, Massimo).

Beyond the palpable nostalgia expressed in the old residents' narratives, the fact remains that both old and new residents, as well as university students share the same conviction that the reinvention of Bicocca as a mixed use space in fact turned the area into no man's land, and created a decaffeinated urbanity 'freed' from the struggles, alliances and rich history that had originally produced this space. Like in most redevelopment projects across the western world, the eradication of the area's social history and working class character is now seen as key to the project's economic success (Fainstein 1983; Lehrer 2006).

\section{Conclusion}

In this article, we made a case for paying closer attention to the role that land and its social mobilisation play in transforming labour/capital relations and enacting urban change. Our intention was twofold. First, to highlight the importance of resurrecting the debate on land, a debate which has been largely neglected in recent years in favour of more 'trendy' debates on 'urban governance' and 'urban cultures'. Second, to highlight the need to take this debate further through systematic empirical research and analysis that teases out the socially embodied and historicallygeographically specific processes that shape the dynamics of urban transformation.

The case study of Bicocca functioned as a heuristic device. By reading the histories of the Pirelli company, its workers, and Pirelli's land at Bicocca side by side, the paper documented how, during each period of crisis, land became the point de capiton of class struggle around which the production of new types of urbanity were renegotiated. First, Bicocca's land was developed as a means to expand production, but also to control workers by introducing scientific management practices. But the same qualities that made Bicocca the showcase of Pirelli's industrial paternalism and Taylorism also facilitated the evolution of Bicocca in the 1960s into a hub for radical industrial action. Subsequently, in response to the industrial decline of the 1970s, Bicocca's reinvention as a 
TechnoCity became the lever both for reclaiming Bicocca's social spaces from Pirelli's militant workers and for saving a troubled Pirelli from decline. The loss of Bicocca as a social space for Pirelli's workers also meant the loss of workers' rights that had been forged through many decades of social struggle.

During Bicocca's most recent transformation through a mixed use speculative real-estate redevelopment project and the mobilization of land as pure financial asset became the final step towards disengaging the traditional working class from any possibility to further mobilize land as an axis for social claims over new urban futures. This disengagement became key for successfully reorienting urban economies towards the services and finance sector, and for establishing a new power nexus between international capital and local social forces. We argue that exposing the overlooked but central role that class struggle over land has played in recent urban transformations, poses a significant challenge to ways of thinking about urban regeneration, social exclusion, and gentrification. It begs for re-telling the stories of class conflict and alliances by inserting land into our research narratives as a catalyst for recent and future urban change.

\section{References}

Anonymous (1969) Tower Block Blocked. Corriere della Sera 8 October Anonymous (1972) 1968-1972. Le lotte alla Pirelli. Milano: Edizioni della libreria Anonymous (1984) Piano della Cassa per il Mezzogiorno. 17 November Anonymous (1986) Agenzia per la promozione dello sviluppo del Mezzogiorno. 1 March Aglietta M (1979) A Theory of Capitalist Regulation. London: New Left Books Agnelli E (1930) L'industria automobilistica. In G Olivetti, P Pirelli, A Pesenti, E Parisi, G Mazzini, C Roncoroni, G Giacomo, C Tarlarini, G Donegani and E Agnelli (eds) Industrie Italiane illustrate dai loro capi (pp269-311). Livorno: Edizioni della rivista L'Unione Industriale Anelli P, Bonvini G and Montenegro A (1985) Pirelli 1914-1980. Strategia aziendale e relazioni industriali nella storia di una multinazionale. Primo tomo. Dalla prima guerra mondiale all'autunno caldo. Milan: F. Angeli

Badcock B (1997) Restructuring and spatial polarization in cities. Progress in Human Geography 21:251-262

Beauregard R A (1994) Capital switching and the built environment. Environment and Planning A 26:715-732

Bell D (1945) Fondo Pirelli L'Unità 25 August

Benenati E (1999) Cento anni di paternalismo aziendale. In S Musso (ed) Tra fabbrica e società: mondi operai nell'Italia del Novecento (pp43-81). Milan: Feltrinelli 
Bertelè U (1993) Pirelli: cronaca di un turnaround annunciato. L’impresa 1993:63-66

Bianchi G, Frigo F, Merli-Brandini P and Merola A (eds) (1971) I CUB: Comitati Unitari di Base.

Ricerca su nuove esperienze di lotta operaia: Pirelli-Borletti-Fatme, Rome: Coines edizioni

Bianchi G (ed) (1979) Grande impresa e conflitto industriale. Ricerca su quattro casi di conflitto sindacale: FIAT, Pirelli, Marzotto, Italcantieri. Roma: Coines

Bigazzi D (1996) Le permanenze del paternalismo: le politiche sociali degli imprenditori italiani tra Otto e Novecento. In M L Betri and D Bigazzi (eds) Ricerche di Storia in onore di Franco Della Peruta (pp36-63). Milan: F. Angeli

Bluestone B and Harrison B (1982) The Deindustrialization of America. New York: Basic Books Bolchini P (1967) La Pirelli: operai e padroni. Roma: Samonáa e Savelli

Bolchini P (1985) Pirelli 1914-1980. Strategia aziendale e relazioni industriali nella storia di una multinazionale. Secondo tomo. Il gruppo Pirelli-Dunlop: gli anni più lunghi. Milan: F. Angeli Bolocan Goldstein M (2003) La Pirelli a Milano. Cenni di storia urbana e vicende recenti. In M Bolocan Goldstein (ed) Trasformazioni a Milano. Pirelli Bicocca direttrice nord-est (pp27-43). Milan: F. Angeli

Bonelli F (1978) Il capitalismo italiano. Linee generali d'interpretazione. In Storia d'Italia, Annali I: Dal feudalesimo al capitalismo (pp1246-1255). Turin: Einaudi

Brenner R (1976) Agrarian class structure and economic development in pre-industrial Europe. Past and Present 70:30-73

Brenner R (2006) The Economics of Global Turbulence. New York: Verso

Cacciari M (1969) Ciclo capitalistico e lotte operaie Montedison Pirelli Fiat 1968. Padova:

Marsilio

Cafagna L (1990) Dualismo e sviluppo nella storia d'Italia. Venice: Marsilio

Cento Bull A (2007) Italian Neofascism. New York: Berghahn Books

Cercola R (1984) L'intervento esterno nello sviluppo industriale del Mezzogiorno. Naples: Guida

Editori

Cherry G E (1996) Bournville, England, 1895-1995. Journal of Urban History 22:493-508

Ciuffetti A (2004) Casa e lavoro: villaggi e quartieri operai in Italia tra Otto e Novecento. Perugia:

Crace

Clark D (1984) Post-Industrial America: A Geographical Perspective. London: Methuen

Coq-Huelva D (2013) Urbanisation and financialisation in the context of a rescaling state: The case of Spain. Antipode 45(5):1213-1231

Colli A (2001) Cent'anni di 'grandi imprese' lombarde. In D Bigazzi and M Meriggi (eds) La Lombardia. Storia d'Italia. Le regioni dall'unità a oggi (pp481-529). Turin: Einaudi

Cox K R (1997) Spaces of Globalization: Reasserting the Power of the Local. New York: Guilford 
Press

D’Agostini F (ed) (1978) Operaismo e centralita operaia, Roma: Editori Riuniti

Dalmasso E (1970) Milano capitale economica d'Italia. Milan: F. Angeli

De Grazia V (1981) Consenso e cultura di massa nell'Italia fascista. Rome: Laterza

Deitrick S and Ellis C (2004) New urbanism in the inner city. Journal of the American Planning Association 70:426-442

De Luna G (2009) Le ragioni di un decennio. 1969-1979. Militanza,violenza,sconfitta, memoria. Milan: Feltrinelli

Dell'Agnese E (2005) Costruzione e ri-costruzione di un paesaggio simbolico. In E Dell'Agnese (ed) La Bicocca e il suo territorio. Memoria e progetto (pp12-22). Milan: Skira

Dewhirst R K (1960) Saltaire. Town Planning Review 31:135-144

Dumenil G and Levy D (2004) Capital Resurgent. Cambridge: Harvard University Press Fainstein S (1983) Restructuring the City: The Political Economy of Urban Redevelopment. New York: Longman

Fumagalli F and Mocera G (2007) Chi vuole uccidere la Pirelli? Indagine sulla crisi di una grande azienda italiana. Milan: Mursia

Gaffney M (2001) The role of ground rent in urban decay and revival. American Journal of Economics and Sociology 60:57-83

Gans H J (1993) From underclass to undercaste: Some observations about the future of the postindustrial economy and its major victims. International Journal of Urban and Regional Research 17(3):327-335

Galdo A (2007) Fabbriche. Turin: Einaudi

Ghianda G (1946) Fondo Pirelli. Nuovo Corriere della Sera 17 May

Gindin C (2003) Marx et la rente foncière. Pensee 335:67-80

Gómez M V (1998) Reflective images: The case of urban regeneration in Glasgow and Bilbao. International Journal of Urban and Regional Research 22(1):106-121

Gotham K F (2009) Creating liquidity out of spatial fixity: Crisis, the secondary circuit of capital, and the subprime mortgage crisis. International Journal of Urban and Regional Research 33(2):355-371

Haila A (1988) Land as a financial asset: The theory of urban rent as mirror of economic transformation. Antipode 20(2):79-101

Hall T and Hubbard P (1996) The entrepreneurial city: New urban politics, new urban geographies? Progress in Human Geography 20:153-174

Hamnett C and Whitelegg D (2007) Loft conversion and gentrification in London: From industrial to postindustrial land use. Environment and Planning A 39:106-124 
Harvey D (1982a) The Limits to Capital. Oxford: Blackwell

Harvey D (1982b) Land rent and the transition to the capitalist mode of production. Antipode 14(3):17-25

Harvey D (1989) From managerialism to entrepreneurialism: The transformation of urban governance in late capitalism. Geographiska Annaler B 71:3-17

Hayter T and Harvey D (1993) The Factory and the City. London: Mansell

Hise G (2001) "Nature's workshop" industry and urban expansion in Southern California, 19001950. Journal of Historical Geography 27:74-92

Hunecke V (1978) Classe operaia e rivoluzione industriale a Milano 1859-1892. Bologna: Il

Mulino

Irace F (1997) L'architettura. In Pirelli 1872-1997, Centoventicinque anni di imprese (pp139-167). Milan: Scheiwiller

Kaika M and Ruggiero L (2013) Land financialization as a "lived" process: The transformation of Milan's Bicocca by Pirelli. European Urban and Regional Studies

DOI:10.1177/0969776413484166

Katz S (1986) Towards a sociological definition of rent: Notes on David Harvey's The Limits To Capital. Antipode 18(1):64-78

King R J (1989) Capital switching and the role of ground rent 3: Switching between circuits, switching between submarkets, and social-change. Environment and Planning A 21:853-880 Krippner G R (2005) The financialization of the American economy. Socio-Economic Review 3:173-208

Lehrer U (2006) Willing the global city: Berlin's cultural strategies of interurban competition after 1989. In N Brenner and R Keil (eds) The Global Cities Reader (pp332-338). New York: Routledge Lever W F (1991) Deindustrialization and the reality of the postindustrial city. Urban Studies 28:983-999

Ley D (1980) Liberal ideology and the postindustrial city. Annals of the Association of American Geographers 70:238-258

Lewis R D (2000) Manufacturing Montreal: The Making of an Industrial Landscape, 1850-1930.

Baltimore: Johns Hopkins University Press

Lewis R D (2004) Manufacturing Suburbs: Building Work and Home on the Metropolitan Fringe. Philadelphia: Temple University Press

Luciani A N (1976) "Movimento Politico e lotte operaie alla Pirelli dal 1943 al 1946.” Unpublished $\mathrm{PhD}$ thesis, Università degli studi di Milano

Lopez-Morales E (2011) Gentrification by ground rent dispossession: The shadows cast by largescale urban renewal in Santiago de Chile. International Journal of Urban and Regional Research 
$35(2): 330-357$

MacLeod G (2002) From urban entrepreneurialism to a "revanchist city"? On the spatial injustices of Glasgow's renaissance. Antipode 34(3):602-624

Memo F (2007) “I nuovi city builder nello sviluppo immobiliare di Milano.” Unpublished PhD thesis, Università degli studi di Milano Bicocca

Mingione E (1996) Urban Poverty and the Underclass: A Reader. Oxford: Blackwell

Mollenkopf J H and Castells M (1991) Dual City: Restructuring New York. New York: Russell Sage Foundation

Molinari L (ed) (1999) Progetto Bicocca 1985-1998. Milan: Skira

Montali E (2009) 1968: l'autunno caldo della Pirelli: il ruolo del sindacato nelle lotte operaie della Bicocca. Roma: Ediesse

Montenegro A (1985) La Pirelli fra le due guerre mondiali. In P Anelli, G Bonvini and A Montenegro (eds) Pirelli 1914-1980. Strategia aziendale e relazioni industriali nella storia di una multinazionale. Primo tomo. Dalla prima guerra mondiale all'autunno caldo (pp19-85). Milan: F. Angeli

Moulaert F, Swyngedouw E and Rodriguez A (eds) (2003) The Globalised City. Oxford: Oxford University Press

Muller E K (2001) Industrial suburbs and the growth of metropolitan Pittsburgh, 1870-1920.

Journal of Historical Geography 27:58-73

Murray F (1983) The decentralisation of production: The decline of the mass-collective worker?

Capital and Class 7:74-99

Myrdal G (1963) Challenge to Affluence. New York: Pantheon

Negrelli S (1983) Sindacato, strategia d'impresa, produttività: il caso Pirelli. Milano: Fondazione regionale Pietro Seveso

Nepoti D (2003) Cronaca della trasformazione di un'area industriale. In M Bolocan Goldstein (ed) Trasformazioni a Milano. Pirelli Bicocca direttrice nord-est (pp61-92). Milan: F. Angeli

Pavese C (1997) I caratteri originali dell'insediamento: un tentativo di analisi comparata. In L Trezzi (ed) Sesto San Giovanni, 1880-1921. Economia e società: la trasformazione (pp ). Milan: Skira

Perulli P (1986) Pirelli 1980-1985. Le relazioni industriali. Negoziando l'incertezza. Milan: F. Angeli

Pinto N (1998) Finance capital revisited. In R Bellofiore (ed) Marxian Economics: A Reappraisal, Vol. I (pp216-232). Basingstoke: Macmillan

Pirelli (1984) Progetto Bicocca. Invito alla progettazione urbanistica e architettonica di un centro tecnologico integrato. Milan: Electa 
Pirelli (1986) Progetto Bicocca. Milan: Electa

Pirelli \& C SpA (2010) Annual Financial Report at 31 December 2010, Vol. I. Milan: Pirelli

Pirelli A (1905) Documenti per la storia delle industrie Pirelli, n. 668. Milan: Archivio Storico Industrie Pirelli (ASIP)

Pirelli A (1946) La Pirelli: vita di una azienda industriale. Milano: Industrie Grafiche A. Nicola \& C.

Pirelli A (1948) Pirelli Technical and Informational Magazine. Milan: Pirelli

Pirelli L (1999) Interview with Leopoldo Pirelli. La Repubblica 27 October

Pirelli SpA (1971) Relazione e Bilancio al 31 dicembre 1970. Milan: Archivio Storico Industrie Pirelli (ASIP)

Pirelli SpA (1976) Rapporto su Ricerca e Sviluppo. Milan: Archivio Storico Industrie Pirelli (ASIP) Pirelli SpA (1992) Relazioni e Bilancio al 31 dicembre 1991. Milan: Archivio Storico Industrie Pirelli (ASIP)

Pirelli SpA (1993) Relazioni e Bilancio al 31 dicembre 1992. Milan: Archivio Storico Industrie Pirelli (ASIP)

Pollard J and Storper M (1996) A tale of twelve cities: Metropolitan employment change in dynamic industries in the 1980s. Economic Geography 72:1-22

Quilley S (2000) Manchester first: From municipal socialism to the entrepreneurial city.

International Journal of Urban and Regional Research 24(3):601-615

Regione Lombardia (1985) Schema di protocollo di intesa per la ristrutturazione dell'area Pirelli Bicocca e relativi processi di rilocalizzazione e di nuovo insediamento. 26 April

Roberts S and Schein R (1993) The entrepreneurial city: Fabricating urban development in Syracuse, New York. Professional Geographer 45:21-33

Rousseau M (2009) Re-imagining the city centre for the middle classes: Regeneration and symbolic policies in "loser cities". International Journal of Urban and Regional Research 33(3):770-788

Rousseau M (2012) Post-Fordist urbanism in France's poorest city: Gentrification as local capitalist strategy. Critical Sociology 38(1):49-69

Savage M, Warde A and Ward K (1993) Urban Sociology, Capitalism, and Modernity. London: MacMillan

Savitch H V (1987) Postindustrial planning in New York, Paris and London. Journal of the American Planning Association 53:80-91

Savini F (2014) What happens to the urban periphery? The political tensions of postindustrial redevelopment in Milan. Urban Affairs Review 50:180-205

Schipper S (2013) Global city formation, gentrification, and the appropriation of ground rent in Frankfurt am Main. Zeitschrift Fur Wirtschaftsgeographie 57:185-200 
Schoenberger E (1988) From Fordism to flexible accumulation: Technology, competitive strategies, and international location. Environment and Planning D: Society and Space 6:245-262

Sclavi M (1974) Lotta di classe e organizzazione operaia: Pirelli Bicocca Milano ('68-'69), OMFIAT Brescia ('54-'72). Milano: G. Mazzotta

Scott A J (1988) Metropolis. Berkeley: University of California Press

Scotto di Luzio A (2001) L'industria dell'Informazione. In D Bigazzi and M Meriggi (eds) La Lombardia. Storia d'Italia. Le regioni dall'unità a oggi (pp ). Turin: Einaudi

Secchia P and Frassati F (1965) Storia della Resistenza. Rome: Editori Riuniti

Sicca L and Izzo F (1995) La gestione dei processi di Turnaround. Un caso esemplare: La Pirelli S.P.A. Naples: Edizioni Scientifiche Italiane

Smith N (1996) The New Urban Frontier: Gentrification and the Revanchist City. New York:

Routledge

Smith N (2002) New globalism, new urbanism: Gentrification as global urban strategy. Antipode 34(3):427-450

Stovall T E (1990) The Rise of the Paris Red Belt. Berkeley: University of California Press Swyngedouw E (1992) The Mammon Quest: "Glocalization", interspatial competition, and the monetary order. In M Dunford and G Kafkalis (eds) Cities and Regions in the New Europe (pp3967). London: Belhaven

Swyngedouw E (2005) Governance innovation and the citizen: The Janus face of governancebeyond-the-state. Urban Studies 42(11):1991-2006

Tribe K (1977) Economic property and theorization of ground rent. Economy and Society 6:68-88 Vicari Haddock S, Tornaghi C and Mugnano S (2005) New visions of the territory: Urban renewal and new public spaces. In E dell'Agnese (ed) La Bicocca e il suo territorio. Memoria e progetto (pp166-193). Milan: Skira

Wallerstein I (1979) The Capitalist World-Economy. Cambridge: Cambridge University Press Walker R A (1974) Urban ground rent: Building a new conceptual framework. Antipode 6(1):51-58 Walker R A (1975) Contentious issues in Marxian value and rent theory: A second and longer look. Antipode 7(1):31-53

Walker R A (1978) Two sources of uneven development under advanced capitalism: Spatial differentiation and capital mobility. Review of Radical Political Economics 10:28-38

Walker R A (2001) Industry builds the city: The suburbanization of manufacturing in the San Francisco Bay Area, 1850-1940. Journal of Historical Geography 27(1):36-57

Walker R and Lewis R D (2001) Beyond the crabgrass frontier: Industry and the spread of North American cities, 1850-1950. Journal of Historical Geography 27(1):3-19

Ward K (2000) From rentiers to rantiers: “Active entrepreneurs", "structural speculators", and the 
politics of marketing the city. Urban Studies 37:1093-1107

Ward K (2002) Strategy and partnership in cities and regions: Economic development and urban regeneration in Pittsburgh. Progress in Human Geography 26:277-278

Wright E O (1994) Interrogating Inequality: Essays on Class Analysis, Socialism, and Marxism. New YorkVerso

Zanetti A M (2003) I lavoratori dell'impresa globale. Le relazioni di lavoro in Pirelli tra strategie globali e destini locali. Milan: F. Angeli

Zimmerman J (2008) From brew town to cool town: Neoliberalism and the creative city development strategy in Milwaukee. Cities 25:230-242

Zukin S and DiMaggio P (1990) Structures of Capital: The Social Organization of the Economy. Cambridge: Cambridge University Press 


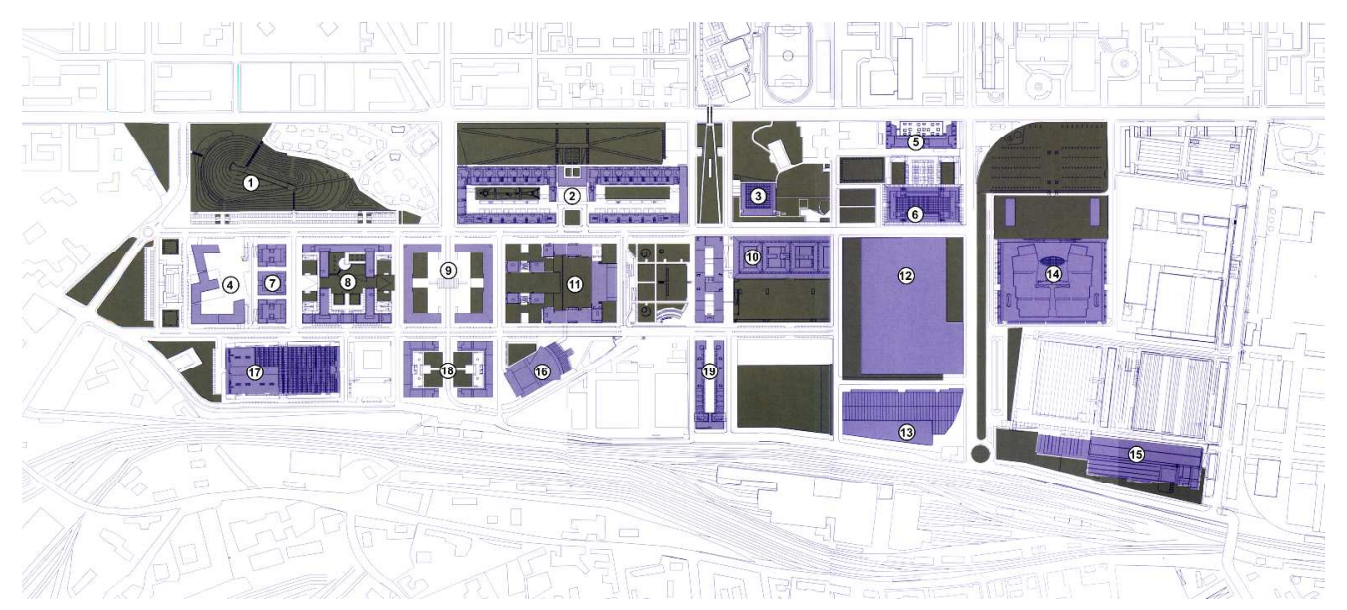

$390 \times 172 \mathrm{~mm}(300 \times 300 \mathrm{DPI})$ 


\begin{tabular}{|c|c|c|}
\hline \multicolumn{2}{|l|}{$\begin{array}{l}\text { PROGETTO BICOCCA (1985-1988) } \\
\text { LAND USE CHANGES }\end{array}$} & \\
\hline - LAND USE BY CATEGORY & $\begin{array}{l}\text { GROSS FLOOR AREAS } \\
\text { AFTER INTERVENTION }\end{array}$ & \\
\hline \multicolumn{2}{|l|}{ XISTING } & \\
\hline - Total land surface of Intervention & $676,000 \mathrm{~m}^{2}$ & \\
\hline $\begin{array}{l}\text { - } \text { Total Gross Floor Areas of Existing Buildings } \\
\text { (plants housing and services) }\end{array}$ & $628,366 \mathrm{~m}^{2}$ & \\
\hline \multicolumn{2}{|l|}{ ROPOSED } & \\
\hline - Industrial Production (incl. new technologies) & $135,227 \mathrm{~m}^{2}$ & \\
\hline - Residential & $132,177 \mathrm{~m}^{2}$ & \\
\hline - Administrative & $130,538 \mathrm{~m}^{2}$ & \\
\hline $\begin{array}{l}\text { - } \text { Research } \\
\text { - University and Higher Education } \\
\text { - Business Services }\end{array}$ & $114,200 \mathrm{~m}^{2}$ & $\begin{array}{l}\text { Total Permissible Gross Floor Area }=\max \\
297,000 \mathrm{~m}^{2}\end{array}$ \\
\hline - Green spaces & $109,143 \mathrm{~m}^{2}$ & \\
\hline - Public services and Parking lots & $49,590 \mathrm{~m}^{2}$ & \\
\hline
\end{tabular}




\section{Page 29 of 30}

Antipode

1

2
3

5

6

7

8

9
10

11

12

13

14

15

16

17

18

19

20

21

22

23

24

25

26

27

28

29

30

31

32

33

34

35

36

37

38

39

40

41

42

43

44

45

46

47

48

\begin{tabular}{|l|l|}
\hline- Squares and pedestrian routes & $46,000 \mathrm{~m}^{2}$ \\
\hline- Traffic circulation (Boulevards and Roads) & $98,000 \mathrm{~m}^{2}$ \\
\hline- Sports facilities & $77,500 \mathrm{~m}^{2}$ \\
\hline
\end{tabular}

49 


\begin{tabular}{l|c|c|c}
\hline PIRELLI GROUP & $\mathbf{1 9 9 1}$ & $\mathbf{1 9 9 2}$ & $\mathbf{1 9 9 3}$ \\
\hline Revenues* & 8,145 & 8,252 & 9,247 \\
\hline Operating results* & 178 & $\mathbf{2 7 8}$ & 339 \\
\hline Net losses* & 673 & 154 & 96 \\
\hline Net worth* & 2,314 & 3,005 & 3,175 \\
\hline Net financial debts* & 3,204 & 2,632 & 2,106 \\
\hline Industrial plants & 102 & 90 & 80 \\
\hline Employees & 51,572 & 45,726 & 42,132 \\
\hline
\end{tabular}

